\title{
DISCONTINUITY IN THE INTERNALIZATION OF THE WORLD TRADE ORGANIZATION RULES: ASSESSING THE DEMOCRATIC DEFICIT CRITIQUE AgAINST THE WORLD TRADE ORGANIZATION DISPUTE SETTLEMENT SYSTEM
}

\author{
YUKA FUKUNAGA*
}

International institutions are often criticized for their democratic deficit. Among these institutions, the World Trade Organization (WTO) dispute settlement system is most frequently targeted. This article focuses on the strength of this critique and aims to refute its factual premise through the examination of several Panel and Appellate Body decisions. The author also argues that the WTO dispute settlement system deliberately leaves a certain degree of discontinuity between members' domestic legal orders and the WTO Agreement, such that the system pays a degree of deference to member states and allows substantial discretion in the process of internalizing the rules of the WTO Agreement within domestic legal orders. Finally, the author concludes that this discontinuity remains strong, and serves to enhance the democratic autonomy of member states instead of defeating it.
Le déficit démocratique des organisations internationales fait souvent l'objet de critiques. Parmi ces organisations, la méthode de règlement de conflit de l'Organisation mondiale du commerce (OMC) est la plus ciblée. Cet article porte sur la force de cette critique et vise à réfuter sa prémisse factuelle par l'examen de plusieurs décisions de son organisme de travail et d'appel. L'auteur fait aussi remarquer que la méthode de règlement de conflit de l'OMC laisse intentionnellement une certaine discontinuité entre les ordres juridiques nationaux des membres et l'Accord instituant l'organisation mondiale du commerce, de sorte que le système a une certaine déférence à l'égard des États membres et laisse beaucoup de discrétion dans le processus d'internalisation des règles de l'Accord au sein des ordres juridiques nationaux. Enfin, l'auteur conclut que cette discontinuité demeure forte et aide à renforcer l'autonomie démocratique des États membres au lieu de la rejeter.

\section{TABLE OF CONTENTS}

I. INTRODUCTION ................................ 1039

II. ILLUSTRATION OF THE REMAINING DISCONTINUITY . . . . . . . . . . . . 1042

A. TRAde ANd ENVIRONMENT DisPutes . . . . . . . . . . . . . . . . . 1043

B. Quarantine Disputes . . . . . . . . . . . . . . . . . . . . . . . 1047

C. Intellectual Property Right Disputes . . . . . . . . . . . . . . 1052

III. Normative VAlues of Remaining Discontinuity . . . . . . . . . . 1056

IV. CONCLUSION ................................. 1059

\section{INTRODUCTION}

International institutions are often criticized for their democratic deficit. Among these institutions, the World Trade Organization (WTO) dispute settlement system has been the most frequent target of the democratic deficit criticism. Various proposals have been put forward for democratizing the dispute settlement system, although different scholars attach different meanings to the term "democratization." 
Despite the ambiguity of the term, it appears to be generally understood that the democratization of the WTO dispute settlement system has two normative implications. ${ }^{1}$ The first implication is that non-state parties, such as individuals and non-governmental organizations (NGOs), should be allowed to participate in the WTO dispute settlement proceedings. For example, it is argued that meetings of panels and the Appellate Body should be open to the public ${ }^{2}$ and that panels and the Appellate Body should accept and take into account unsolicited amicus curiae briefs submitted by non-state parties. ${ }^{3}$ The other normative implication is that non-economic interests and values should be reflected in the dispute settlement system. Proposals in this direction include the direct application of international legal rules other than those contained in the Marrakesh Agreement Establishing the World Trade Organization ${ }^{4}$ (hereinafter non-WTO international legal rules) in the WTO disputes ${ }^{5}$ as well as the reflection of non-economic interests and values in the interpretation of the WTO Agreement. ${ }^{6}$ In some of the recent cases, panels and the Appellate Body responded to the democratization movement by, for example, opening their meetings to the public, accepting amicus curiae briefs, and taking into account non-WTO international legal rules. However, it is debatable whether the newly developed practice of the panels and the Appellate Body produced truly "democratic" consequences. ${ }^{7}$

The objective of this article is not to assess the individual proposals for democratization. Instead, it addresses a more fundamental question: Why are international institutions required to be democratic despite the fact that the concept of democracy was originally applied to national societies? More specifically, this article questions the validity of the

1 The two implications of democratization pointed out in this article are also often discussed as the core of the "constitutionalization" of the WTO dispute settlement system. The core elements of constitutionalization, which is also an ambiguous term, are suggested to contain coherence, unity, community, deliberation, and social legitimacy: see Deborah Z. Cass, The Constitutionalization of the World Trade Organization: Legitimacy, Democracy, and Community in the International Trading System (Oxford: Oxford University Press, 2005) at 31-48; see also John H. Jackson, Sovereignty, the WTO and Changing Fundamentals of International Law (Cambridge: Cambridge University Press, 2006) at 222-27; Ernst-Ulrich Petersmann, "Multilevel Trade Governance in the WTO Requires Multilevel Constitutionalism” in Christian Joerges \& Ernst-Ulrich Petersmann, eds., Constitutionalism, Multilevel Trade Governance and Social Regulation (Oxford: Hart, 2006) 5; John O. McGinnis \& Mark L. Movsesian, “The World Trade Constitution” (2000) 114 Harv. L. Rev. 511.

2 See e.g. J.H.H. Weiler, "The Rule of Lawyers and the Ethos of Diplomats: Reflections on the Internal and External Legitimacy of WTO Dispute Settlement” (2002) 13 Am. Rev. Int'l Arb. 177 at 191. Some panel and Appellate Body meetings were already open to the public.

3 See e.g. Steve Charnovitz, "Participation of Nongovernmental Organizations in the World Trade Organization” (1996) 17 U. Pa. J. Int’l Econ. L. 331; Daniel C. Esty, “Non-Governmental Organizations at the World Trade Organization: Cooperation, Competition, or Exclusion” (1998) 1 J. Int'l Econ. L. 123. The Appellate Body has confirmed that it has the authority to accept unsolicited amicus curiae briefs: United States - Import Prohibition of Certain Shrimp and Shrimp Products (Complaint by Malaysia, Thailand, and Pakistan) (1998), WTO Doc. WT/DS58/AB/R at para. 9 (Appellate Body Report) [US - Shrimp, Appellate Body].

415 April 1994, 1867 U.N.T.S. 154 (entered into force 1 January 1995) [WTO Agreement].

5 See e.g. Joost Pauwelyn, Conflict of Norms in Public International Law: How WTO Law Relates to Other Rules of International Law (Cambridge: Cambridge University Press, 2003).

6 See e.g. Robert Howse, “Adjudicative Legitimacy and Treaty Interpretation in International Trade Law: The Early Years of WTO Jurisprudence” in J.H.H. Weiler, ed., The EU, the WTO and the NAFTA: Towards a Common Law of International Trade? (New York: Oxford University Press, 2000) 35 at 6268; Philip M. Nichols, “Trade Without Values” (1996) 90 Nw. U.L. Rev. 658 at 709-18.

7 Problems ensuing from the democratization of the dispute settlement system will be pointed out in Part III of this article. 
premise underlying the democratic deficit critique against the dispute settlement system. In my view, there are normative and factual premises behind the critique. The normative premise, which is not discussed in this article, ${ }^{8}$ is that the principle of democracy is taking on increasing significance not only at the national level but also at the global level. ${ }^{9}$ It is argued that democracy in international law, which once exclusively meant the promotion of democracy at the national level through international law, ${ }^{10}$ is now expanding its scope to include democratization of international law process itself. ${ }^{11}$ The alleged emergence of global democracy forms the normative premise underlying the democratic critique against international institutions.

This article focuses on the factual premise of the critique, which is described as follows. As a result of the permeating influence of the dispute settlement system over the domestic laws and policies of WTO member states, the once separate orders of international law and domestic law are being merged into a single continuous legal process, thereby eroding the domestic democratic autonomy of the member states. Based on such a premise, it is argued that the eroded democracy at the national level needs to be supplemented by democracy at the international level. This is why the WTO dispute settlement system is facing the democratization demand.

The objective of this article is to refute the factual premise of the critique and argue that the dispute settlement system deliberately leaves a certain degree of discontinuity between the domestic legal orders and the WTO Agreement in the sense that the review in the system pays a degree of deference to member states' laws and policies and that the member states enjoy substantial discretion in internalizing the rules of the WTO Agreement in their domestic legal orders. Discontinuity means, in this article, that the distinction between international law and the domestic legal orders, though blurred, still exists and that international legal rules, including the WTO Agreement, do not directly affect the domestic legal order. This discontinuity enables the member states to autonomously decide how to align their domestic laws and policies with the WTO Agreement and also preserves and promotes national democracy in the member states. Thus, the existence of discontinuity raises a question about the need to democratize the dispute settlement system.

In order to substantiate my argument, Part II of this article conducts an empirical analysis of the dispute settlement system. It shows that a degree of discontinuity has often been left by the dispute settlement system in the past cases at the WTO. Part III then argues that the existence of discontinuity is not only an empirical fact but also a normative value and that

$8 \quad$ I have discussed this in a previous work, see Yuka Fukunaga, "Participation of Private Parties in the WTO Dispute Settlement Processes: Treatment of Unsolicited Amicus Curiae Submissions” (2007) 4 Soochow Law Journal 99 at 107-10 [Fukunaga, "Participation”].

$9 \quad$ See e.g. David Held, Democracy and the Global Order: From the Modern State to Cosmopolitan Governance (Stanford: Stanford University Press, 1995).

10 See e.g. Thomas M. Franck, “The Emerging Right to Democratic Governance” (1992) 86 A.J.I.L. 46; James Crawford, “Democracy and International Law” (1993) 64 Brit. Y.B. Int’l L. 113.

11 Cf. Eric Stein, “International Integration and Democracy: No Love at First Sight” (2001) 95 A.J.I.L. 489. A question remains as to whether the current international society is ready for the concept of global democracy, see Robert A. Dahl, On Democracy (New Haven: Yale University Press, 1998) at 37-38. 
it should be preserved in order to accommodate the diversity in the global society. Part IV summarizes the article.

\section{ILLUSTRATION OF THE REMAINING DISCONTINUITY}

The democratic deficit critique is often derived from the factual premise that the dispute settlement system reinforces the continuity between the domestic legal orders and the WTO Agreement. As the scope of the WTO Agreement expands to cover not only border measures but also domestic regulations, more domestic law becomes subject to the rules of the WTO Agreement. The continuity suggests that the WTO Agreement directly determines the content of the domestic law of WTO member states without allowing the member states to craft their policies autonomously. In other words, two distinct legal orders of international law, the WTO Agreement in this case and domestic law, are now considered as a single continuous legal process.

The democratic deficit critique often assumes that the continuity is reinforced by the dispute settlement system in the sense that the dispute settlement system may overrule and invalidate member states' measures when they are found to be inconsistent with the WTO Agreement. In other words, it is assumed that the WTO Agreement is directly enforced within the domestic legal orders by the dispute settlement system regardless of national democratic support for the measures concerned. Therefore, it is argued that national democracy is allegedly eroded by the reinforced continuity and needs to be supplemented by the democratization of the dispute settlement system itself.

More broadly, growing attention has been paid to the continuity between the international law in general and the domestic legal orders, which is often described as the "blurring" distinction between the two legal orders. ${ }^{12}$ Some even suggest the emergence of "transnational law"13 or a "global legal order"14 as an alternative, or addition to, the traditional dichotomy between international and domestic law. In fact, the scope of international law has been expanding to cover issues that were once regarded as solely domestic issues, and the expanding law is applied more vigorously through the legalization and judicialization of international relations. ${ }^{15}$ These developments in international law have a profound impact on domestic laws and policies. Given these circumstances, there has been

Harold Hongju Koh, "Transnational Legal Process” (1996) 75 Neb. L. Rev. 181 at 183-86; Harold Hongju Koh, “Why Do Nations Obey International Law?” (1997) 106 Yale L.J. 2599 at 2645-58. See also Anne-Marie Slaughter, A New World Order (Princeton: Princeton University Press, 2004) at 5-14, 171-95.

13 See e.g. Philip C. Jessup, Transnational Law (New Haven: Yale University Press, 1956) at 1-16.

14 See e.g. Yishai Blank, “The City and the World” (2006) 44 Colum. J. Transnat'l L. 875 at 888-90; Benedict Kingsbury, Nico Krisch \& Richard B. Stewart, "The Emergence of Global Administrative Law” (2005) 68:3 Law \& Contemp. Probs. 15; Daniel C. Esty, “Good Governance at the Supranational Scale: Globalizing Administrative Law” (2006) 115 Yale L.J. 1490.

15 See e.g. Judith L. Goldstein et al., eds., Legalization and World Politics (Cambridge, Mass.: MIT Press, 2001). 
increasing momentum in the efforts to achieve democracy not only at the national level but also at the international level. ${ }^{16}$

However, while the relationship between the international legal order and the domestic legal orders is becoming more dynamic, the fact that discontinuity remains between them should not be neglected. As for the WTO, the dispute settlement system deliberately leaves a certain degree of discontinuity between the domestic legal orders and the WTO Agreement. Despite the profound impact of the international legal obligations derived from the dispute settlement system, WTO member states retain the discretion to decide, through their domestic democratic processes, how to internalize the rules of the WTO Agreement and dispute settlement decisions in their domestic legal orders.

In order to demonstrate the remaining discontinuity, this section examines how panels and the Appellate Body have reviewed measures adopted by WTO member states. ${ }^{17}$ It also discusses how the member states have internalized the adverse rulings issued by the panels and the Appellate Body in their domestic legal orders. ${ }^{18}$ From among the numerous disputes before the panels and the Appellate Body, the following subsections examine the following three types of disputes that highlight the apparent tension and remaining discontinuity between domestic laws and policies and the WTO Agreement: trade and environment disputes, quarantine disputes, and intellectual property rights disputes.

\section{A. Trade ANd ENVIRonMent Disputes}

This Part reviews trade and environment disputes, in which trade-restrictive measures of WTO member states, mostly the United States, adopted to protect the environment were subject to review by panels and the Appellate Body. Classic examples of this type of dispute are the United States - Restrictions on Imports of Tuna ${ }^{19}$ cases in the General Agreement on Tariffs and Trade ${ }^{20}$ era. In these cases, the U.S. banned the import of tuna caught by methods that did not meet its dolphin protection standards. The GATT Panels found that the import ban was inconsistent with art. XI of the GATT and not justified by art. XX of the GATT. The rulings met with strong opposition from environmental groups. In its wake, "trade

16 Kingsbury, Krisch \& Stewart, supra note 14 at 23-25, 27-42; B.S. Chimni, “Co-Option and Resistance: Two Faces of Global Administrative Law” (2005) 37 N.Y.U.J. Int’l L. \& Pol. 799 at 801-806; Esty, supra note 14 at 1530-34. See also Yuka Fukunaga, "Global Economic Institutions and the Autonomy of the Development Policy: A Pluralist Approach” (Paper presented to The New Zealand Centre of International Economic Law Inaugural Conference, Victoria University of Wellington, 14 December 2007) [on file with the author, forthcoming as a book chapter] (arguing that underlying the alleged emergence of global administrative law is the growing continuity between the international legal order and the domestic legal orders).

17 For general analyses on how panels and the Appellate Body have reviewed domestic laws, see e.g. Matthias Oesch, Standards of Review in WTO Dispute Resolution (Oxford: Oxford University Press, 2003) at 188-206.

18 For more comprehensive discussions on the implementation of Dispute Settlement Body (DSB) recommendations, see e.g. Yuka Fukunaga, "Securing Compliance through the WTO Dispute Settlement System: Implementation of DSB Recommendations” (2006) 9 J. Int’l Econ. L. 383.

19 United States - Restrictions on Imports of Tuna (Complaint by Mexico) (1991), GATT Doc. DS21/R; United States - Restrictions on Imports of Tuna (Complaint by European Economic Community) (1994), GATT Doc. DS29/R.

2030 October 1947, 55 U.N.T.S. 187 (entered into force 1 January 1948) [GATT]. 
and environment" became one of the most controversial issues in the WTO, which was established half a year after the rulings. Discontinuity can be well illustrated by how the WTO dispute settlement system has handled environment-related disputes amidst opposition.

There are two WTO cases involving the trade-related environmental measures adopted by the U.S. The first case is United States - Standards for Reformulated and Conventional Gasoline, in which the measure at issue was the U.S. regulation on the composition and emissions effects of gasoline. The regulation was promulgated in order to improve air quality in the U.S. ${ }^{21}$ It required domestic and foreign refiners to improve the quality of gasoline beyond the baselines, which were determined in the following discriminatory manner. For domestic refiners, the baselines were established individually based on the quality of gasoline produced in the past by each refiner. On the other hand, for foreign refiners, because of the difficulty in investigating the quality of gasoline produced by foreign refiners in the past, the uniform statutory baseline was applied for all foreign refiners. The chief issue for the Panel and the Appellate Body was whether the regulation, found to be inconsistent with art. III(4) of the GATT by the Panel, was justified under art. XX of the GATT. The Appellate Body found that although the regulation at issue fell within the scope of para. (g) of art. XX, it did not meet the requirement of the chapeau of art. XX because of the discriminatory nature of how the baselines were applied.

In United States - Import Prohibition of Certain Shrimp and Shrimp Products, the next trade and environment dispute involving the U.S., the U.S. prohibited the import of shrimp from countries that did not use sea turtle protection devices that were "comparable" to those adopted by the U.S. ${ }^{22}$ Once again, the issue concerned the question of whether the prohibition, conceded by the U.S. to be a violation of art. XI(1) of the GATT, was justified by art. XX of the GATT. The Appellate Body found that although the measure at issue fell within the terms of para. (g) of art. XX, it failed to meet the requirement of the chapeau of art. XX because of the lack of flexibility and transparency in the guidelines used to assess the "comparability" of protection tools. ${ }^{23}$ The Appellate Body also stated that the measure was not applied consistently with the chapeau because there was an absence of serious efforts by the U.S. to establish co-operative arrangements with the complainants to the dispute regarding the protection of sea turtles. ${ }^{24}$ The Appellate Body therefore concluded that the measure was not justified by art. XX of the GATT.

As known widely, the rulings of the Appellate Body in these cases provoked criticism against the WTO to the effect that the Panel and the Appellate Body only took into account economic interests and dismissed non-economic interests and values of non-state stakeholders, that is, the protection of the environment supported by NGOs. The democratic

$21 \quad$ United States - Standards for Reformulated and Conventional Gasoline (Complaint by Venezuela) (1996), WTO Doc. WT/DS2/R (Panel Report) [US - Gasoline]; United States - Standards for Reformulated and Conventional Gasoline (Complaint by Venezuela)(1996), WTO Doc. WT/DS2/AB/R (Appellate Body Report).

22 United States - Import Prohibition of Certain Shrimp and Shrimp Products (Complaint by Malaysia and Thailand) (1998), WTO Doc. WT/DS58/R at para. 2.12 (Panel Report) [US - Shrimp, Panel]; US - Shrimp, Appellate Body, supra note 3.

23 US - Shrimp, Appellate Body, ibid. at paras.146-84.

24 Ibid. at paras. 125-45. 
deficit critique is also at least partly rooted in these rulings, which were alleged to have overruled and invalidated the environmental policies of the U.S. despite the democratic support for the policies. However, as illustrated below, the criticism pays almost exclusive attention to the conclusions of the Panel and the Appellate Body in these cases and fails to see the true impact of these findings on the domestic laws and policies of the U.S.

For example, in US - Gasoline, the U.S. amended the measure at issue 13 months after the adoption of the Dispute Settlement Body (DSB) recommendation. ${ }^{25}$ The amended regulation allows foreign refiners to use individual baselines so long as certain requirements are met, while providing for several adaptation measures to offset any adverse environmental impact resulting from the amendment. ${ }^{26}$ While the amendment added flexibility to the U.S. gasoline regulation, it does not prevent the U.S. from maintaining its policies that "fully protect public health and the environment, and at the same time are consistent with the obligations of the United States under the WTO,” as the U.S. government acknowledges. ${ }^{27}$

A similar observation applies to the domestic implementation of the adverse ruling in US — Shrimp. In US - Shrimp, in order to implement the DSB recommendation, the U.S. issued a revised measure with the following purposes: (1) introduce greater flexibility in the consideration of the measure's "comparability," and (2) elaborate a timetable and the procedures for certification decisions to increase the transparency and predictability of the certification process. ${ }^{28}$ In addition, the U.S. redoubled its efforts to negotiate and reach an agreement on the protection of sea turtles with the complainants and decided to offer them technical training on the protection tools as well. ${ }^{29}$ In the subsequent proceedings under art. 21(5) of the Understanding on Rules and Procedures Governing the Settlement of Disputes, ${ }^{30}$ the Panel and Appellate Body confirmed that the revised measure was applied in a manner that met the requirements under the chapeau of art. XX of the GATT and was justified by the provision. ${ }^{31}$ Thus, the subsequent developments of the case illustrate that the measures taken to implement the DSB recommendation in US - Shrimp did not cause any interference with the U.S. policy of protecting sea turtles.

The flexibility and deference accorded to the non-trade policies of WTO member states can also be recognized in other disputes involving art. XX of the GATT and art. XIV of the General Agreement on Trade in Services. ${ }^{32}$ One of the illustrating cases is United States -

25 United States - Standards for Reformulated and Conventional Gasoline (1997), WTO Doc. WT/DS2/10/Add.7 (Status Report).

Regulations of Fuels and Fuel Additives, 40 C.F.R. §80.94 (2008).

62 Fed. Reg. 45533 at 45535 (1997).

64 Fed. Reg. 36946 (1999).

See e.g. United States — Import Prohibition of Certain Shrimp and Shrimp Products (1999), WTO Doc. WT/DS58/15 (Status Report).

15 April 1994, 1869 U.N.T.S. 401 (entered into force 1 January 1995) [DSU].

United States - Import Prohibition of Certain Shrimp and Shrimp Products (Recourse to Article 21.5 by Malaysia) (2001), WTO Doc. WT/DS58/RW (Panel Report); United States - Import Prohibition of Certain Shrimp and Shrimp Products (Recourse to Article 21.5 by Malaysia) (2001), WTO Doc. WT/DS58/AB/RW (Appellate Body Report).

3215 April 1994, 1869 U.N.T.S. 183 (entered into force 1 January 1995) [GATS]. Article XIV of the GATS is an equivalent of art. XX of the GATT in trade in services. 
Measures Affecting the Cross-Border Supply of Gambling and Betting Services. ${ }^{33}$ In this case, the Panel and the Appellate Body examined whether the U.S. federal laws at issue, which prohibited internet gambling contrary to arts. XVI(1) and XVI(2) of the GATS in order to combat organized crimes and protect minors, were justified by art. XIV(a) of the GATS. According to art. XIV(a) of the GATS, nothing in the GATS shall prevent the adoption or enforcement of measures necessary to protect public morals or to maintain public order as long as such measures are not applied in a manner that would constitute a means of arbitrary or unjustifiable discrimination between countries where like conditions prevail, or a disguised restriction on trade in services.

Following the approach of the Appellate Body in the previous cases on art. XX of the GATT, the Panel afforded flexibility to the content of the terms "public morals" and "public order" as provided in art. XIV(a) of the GATS by stating that they "can vary in time and space, depending upon a range of factors, including prevailing social, cultural, ethical and religious values." ${ }^{34}$ In addition, the Panel stated that member states "should be given some scope to define and apply for themselves the concepts of 'public morals' and 'public order' in their respective territories, according to their own systems and scales of values."35 Although the Appellate Body subsequently found that the laws did not meet the requirements of the chapeau of art. XIV of the GATS and were not justified by the provision, it confirmed that the U.S. was free to protect "public morals" and "public order" in accordance with its preferences. $^{36}$

To sum up this subsection, in the disputes involving trade and non-trade policies, the U.S. did not have to abandon its non-trade policies but rather was required to merely modify the policies' unilateral nature and cure their lack of flexibility. The panels and the Appellate Body took sufficient caution in making reviews not to interfere with the autonomy of the U.S. regarding its non-trade policies. ${ }^{37}$ The U.S. was allowed to pursue the non-trade policies

33 United States - Measures Affecting the Cross-Border Supply of Gambling and Betting Services (Complaint by Antigua) (2004), WTO Doc. WT/DS285/R (Panel Report) [US — Gambling, Panel]; United States - Measures Affecting the Cross-Border Supply of Gambling and Betting Services (Complaint by Antigua) (2005), WTO Doc. WT/DS285/AB/R (Appellate Body Report [US Gambling, Appellate Body].

US - Gambling, Panel, ibid. at para. 6.461.

Ibid. There was no appeal on this particular finding.

US - Gambling, Appellate Body, supra note 33. The deferential approach is also followed in other disputes involving art. XX of the GATT: see e.g. European Communities - Measures Affecting Asbestos and Asbestos-Containing Products (Complaint by Canada) (2001), WTO Doc. WT/DS135/AB/R at para. 168(Appellate Body Report); Brazil-Measures Affecting Imports of Retreaded Tyres (Complaint by the European Communities) (2007), WTO Doc. WT/DS332/AB/R at para. 140 (Appellate Body Report).

37 See e.g. US - Shrimp, Panel, supra note 22 at para. 9.1; US - Shrimp, Appellate Body, supra note 3 at paras. 185-86; see also Canada - Certain Measures Concerning Periodicals (Complaint by the United States) (1997), WTO Doc. WT/DS31/R (Panel Report); Canada - Certain Measures Concerning Periodicals (Complaint by the United States) (1997), WTO Doc. WT/DS31/AB/R (Appellate Body Report) (the Panel and Appellate Body findings may be criticized as posing a threat to the cultural identity of Canada. To assess the reasonability of the findings, the special treatment of culture in the GATS as well as the distinction between goods and services needs to be carefully reviewed). 
of its choice as long as they were consistent with the minimal conditions provided for in the WTO Agreement. ${ }^{38}$

In more general terms, the analysis in this subsection suggests that there remains discontinuity between the WTO Agreement and the domestic legal orders. The WTO Agreement does not determine the content of the domestic law of the WTO member states. Rather, it remains within the discretion of the WTO member states to determine how to adjust their domestic law to the rules of the WTO Agreement. The WTO Agreement contains flexibility regarding its domestic implementation and the flexibility is not constrained by the dispute settlement system. In light of the discretion reserved for the WTO member states in the internalization of the WTO Agreement and rulings by the dispute settlement system, it would be erroneous to assume that the domestic legal orders and the WTO Agreement are being merged into a single continuous legal process.

\section{B. QUARANTINE DISPUTES}

The Agreement on the Application of Sanitary and Phytosanitary Measures ${ }^{39}$ recognizes that no WTO member state should be prevented from adopting or enforcing measures, such as quarantine measures, necessary to protect human, animal, or plant life or health. ${ }^{40}$ Since quarantine measures involve vital interests of member states, that is, human life and health, the excessive review of member states' quarantine policies by panels and the Appellate Body could create tension with the democratic autonomy of the member states. The examination below shows that panels and the Appellate Body have been careful in most cases not to interfere with the autonomy of the member states. A degree of discontinuity between the SPS Agreement and quarantine policies of member states has been left by the panels and the Appellate Body in the sense that neither the SPS Agreement nor the dispute settlement system can determine the quarantine policies of the WTO member states. The examination in this subsection also points out that the discretion left regarding the implementation of DSB recommendations in the disputes involving the SPS Agreement has allowed the respondents to internalize adverse rulings within their domestic legal order in a flexible manner.

The analysis begins with the standard of review adopted by panels and the Appellate Body in interpreting and applying provisions of the SPS Agreement. The standard of review adopted in quarantine disputes strikes a careful balance between the need to respect member states' policy autonomy and ensuring compliance with the SPS Agreement. The Appellate Body articulated the standard of review for quarantine disputes in $E C-$ Measures

38 This argument may be construed to suggest that there is no true conflict between the WTO rules and other international legal rules, which is generally the case. However, there may be a limited number of cases in which a true conflict exists among these rules, which is known as the fragmentation of international law. The next Part argues, though briefly, that discontinuity enables each state to resolve the fragmentation of international legal rules in the domestic legal orders. Ibid., Preamble. 
Concerning Meat and Meat Products (Hormones) and Australia - Measures Affecting Importation of Salmon. ${ }^{41}$

In EC - Hormones, the Appellate Body first noted: "The standard of review appropriately applicable in proceedings under the SPS Agreement, of course, must reflect the balance established in that Agreement between the jurisdictional competences conceded by the Members to the WTO and the jurisdictional competences retained by the Members for themselves." 42 It then stated that under art. 3(3) of the SPS Agreement, a member state has an autonomous right to determine its own appropriate level of sanitary protection different from the relevant international standard, although such right is not absolute or unqualified. ${ }^{43}$ Similarly, in Australia - Salmon, the Appellate Body, in examining art. 5(6) of the SPS Agreement, ${ }^{44}$ stated that art. 11 of the DSU does not entitle the Panel or the Appellate Body to substitute its own reasoning regarding the level of protection for that expressed consistently by Australia, the respondent, and that the determination of the appropriate level of protection is a prerogative of the member state concerned and not of a panel or of the Appellate Body. ${ }^{45}$

Thus, the review by panels and the Appellate Body does not question the appropriateness of the level of protection determined by a member state and is limited to whether the member state complied with the conditions provided in the SPS Agreement in achieving the desired level of protection. The deferential approach to the interpretation of the SPS Agreement rightly preserves discontinuity between the SPS Agreement and domestic SPS measures. In other words, the SPS Agreement does not directly determine the content of the SPS measures to be adopted by WTO member states, and WTO member states are allowed to pursue quarantine policies of their own choice as long as the conditions in the SPS Agreement are met. $^{46}$

41 EC - Measures Concerning Meat and Meat Products (Hormones) (Complaint by the United States and Canada) (1998) WTO Docs. WT/DS26/AB/R, WT/DS48/AB/R (Appellate Body Report) [EC Hormones]; Australia - Measures Affecting Importation of Salmon (Complaint by Canada) (1998), WTO Doc. WT/DS18/AB/R (Appellate Body Report) [Australia - Salmon, Appellate Body].

$42 \quad$ EC - Hormones, ibid. at para. 115.

$43 \quad$ Ibid. at paras. 172-73.

$44 \quad$ Article 5(6) of the SPS Agreement, supra note 39, states "when establishing or maintaining sanitary or phytosanitary measures to achieve the appropriate level of sanitary or phytosanitary protection, Members shall ensure that such measures are not more trade-restrictive than required to achieve their appropriate level of sanitary or phytosanitary protection, taking into account technical and economic feasibility.”

45 Australia - Salmon, Appellate Body, supra note 41 at paras. 198-99. The Appellate Body added that member states are required to determine the level with sufficient precision (at para. 207).

46 The Agreement on Implementation of Article VI of the General Agreement on Tariffs and Trade 1994, 15 April 1994, 1868 U.N.T.S. 201, art. 17.6 (entered into force 1 January 1995), provides for the explicit deferential standard of review for anti-dumping disputes, although its real impact is unclear: see Steven P. Croley \& John H. Jackson, "WTO Dispute Procedures, Standard of Review, and Deference to National Governments” (1996) 90 A.J.I.L. 193; Yuka Fukunaga, “International Harmonization of AntiDumping: Standard of Review under Article 17.6(ii) of Anti-Dumping Agreement” (2002) 53 Journal of Social Science 23. 
It should be cautioned, however, that the standard of review, if applied improperly, could remove discontinuity and threaten the policy autonomy of member states. ${ }^{47}$ This concern became reality when the Appellate Body examined the sufficiency of scientific evidence under art. 5(7) of the SPS Agreement in a narrow manner. Article 5(7) states in cases where relevant scientific evidence is insufficient, a member may provisionally adopt sanitary or phytosanitary measures on the basis of available pertinent information. In Japan - Measures Affecting the Importation of Apples, the Panel and the Appellate Body examined whether relevant scientific evidence was insufficient in the sense of art. 5(7). ${ }^{48}$ The Appellate Body first stated that “'relevant scientific evidence' will be 'insufficient' within the meaning of Article 5(7) if the body of available scientific evidence does not allow, in quantitative or qualitative terms, the performance of an adequate assessment of risks as required under Article 5.1 and as defined in Annex A to the SPS Agreement."49 It also noted that "insufficiency of scientific evidence" and "scientific uncertainty" were not interchangeable concepts, ${ }^{50}$ and then found that "relevant scientific evidence" is insufficient "where a lot of scientific research has been carried out on a particular issue without yielding reliable evidence."51 This interpretation overly narrows down the scope of art. 5(7) because panels and the Appellate Body may admit the sufficiency of evidence as long as reliable evidence is yielded by "a lot of scientific research"52 even if the yielded evidence conflicts with each other. Thus, according to the interpretation, a mere showing of conflicting evidence does not necessarily demonstrate the insufficiency of evidence in the sense of art. 5(7). In order to demonstrate the insufficiency of evidence, a member state adopting a quarantine measure has to present conflicting evidence that goes so far as to deny the ability of other evidence to allow the performance of an adequate risk assessment. ${ }^{53}$ The interpretation of the "insufficiency of evidence" in such a narrow manner could jeopardize the policy autonomy of the WTO member states in conducting scientific analysis. ${ }^{54}$

In addition to the standard of review, discontinuity in quarantine disputes is also sustained by the flexibility regarding the implementation of DSB recommendations as allowed generally in the DSU. For example, in Australia — Salmon, the Panel and the Appellate Body

In EC - Hormones, supra note 41, the Appellate Body stated that the requirement of "sufficient scientific evidence" under Article 2.2 is "essential for the maintenance of the delicate and carefully negotiated balance in the SPS Agreement between the shared, but sometimes competing, interests of promoting international trade and of protecting the life and health of human beings" (at para. 177). Japan - Measures Affecting the Importation of Apples (Complaint by the United States) (2003), WTO Doc. WT/DS245/R at paras. 8.67-8.224 (Panel Report) [Japan - Apples, Panel]; Japan - Measures Affecting the Importation of Apples (Complaint by the United States) (2003), WTO Doc. WT/DS245/AB/R at paras. 152-68, 175-88 (Appellate Body Report) [Japan - Apples, Appellate Body]. Japan - Apples, Appellate Body, ibid. at para. 179.

Ibid. at para. 184.

Ibid. at para. 185.

Ibid.

Canada - Continued Suspension of Obligations in the EC - Hormones Dispute (Complaint by the European Communities (2008), WTO Doc. WT/DS321/R at paras. 7.579-7.626 (Panel Report); United States - Continued Suspension of Obligations in the EC - Hormones Dispute (Complaint by the European Communities) (2008), WTO Doc. WT/DS320/R at paras. 7.604-7.648 (Panel Report); see also European Communities - Measures Affecting the Approval and Marketing of Biotech Products (Complaint by the United States, Canada, and Argentina) (2006), WTO Docs. WT/DS291/R, WT/DS292/R, WT/DS293/R at paras. 7.3232-7.3246 (Panel Report).

$54 \quad$ The approach of the Appellate Body would contradict its own previous observation that art. 5(7) reflects the precautionary principle: see EC - Hormones, supra note 41 at para. 124. 
found that Australia's quarantine measure for uncooked salmon imported from Canada violated its obligations under the SPS Agreement, such as arts. 2(2), 2(3), 5(1), and 5(5)..$^{55}$ Following the findings, Australia was recommended by the DSB to bring its quarantine measure into conformity with its obligations under the SPS Agreement. While Australia replaced the measure at issue with a new measure, the state government of Tasmania enacted a measure that effectively prohibited the import of fresh, chilled, or frozen salmon from Canada. Subsequently, these implementation measures, including the Tasmanian ban, were found to be inconsistent with the obligations under the SPS Agreement in the proceedings under art. 21(5) of the DSU. ${ }^{56}$

What is worth mentioning about this dispute is that the solution agreed to by disputing parties after the DSU art. 21(5) proceedings in effect tolerates the Tasmanian ban that was found to violate the SPS Agreement.$^{57}$ While Australia agreed with Canada, the complainant, to permit the import of uncooked salmon under certain conditions, ${ }^{58}$ it successfully induced Canada to tolerate the existence of the Tasmanian ban on the condition that the Australian government would continue to press the Tasmanian government to revoke it. What this case shows is that adverse rulings by the dispute settlement system do not necessarily force the respondent to withdraw the measures concerned. Discontinuity is left by the dispute settlement system in that the parties have options on how to reflect the rulings in a solution to the dispute. It should also be noted that the dispute settlement system does not penalize the lack of implementation of DSB recommendations when the parties reach a mutually agreed solution to tolerate the non-implementation. ${ }^{59}$ In this case, the discontinuity allowed Australia to protect the interests of the most affected stakeholder in the dispute - the Tasmanian salmon industry-while at the same time satisfying the interests of the complainant, namely Canada.

The implementation of DSB recommendations in quarantine disputes involving Japan also show an interesting development. Japan's quarantine measures were subject to two dispute settlement proceedings brought by the U.S. First, in Japan - Measures Affecting Agricultural Products, the Panel and the Appellate Body found that Japan's quarantine measure violated the provisions of the SPS Agreement, ${ }^{60}$ and Japan was recommended to bring the quarantine measure at issue into conformity with its obligations under the SPS WT/DS18/R (Panel Report); Australia - Salmon, Appellate Body, supra note 41 at paras. 119-38, 14378.

Australia - Measures Affecting Importation of Salmon (Recourse to Article 21.5 by Canada) (2000), WTO Doc. WT/DS18/RW (Panel Report).

57 History 536 at 549.

58 Australian Quarantine and Inspection Service (Department of Agriculture Fisheries and Forestry), Animal Quarantine Policy Memorandum 2000/26: Importation of Salmonid Product, Advice on Quarantine Requirements, online: Department of Agriculture, Fisheries and Forestry <http://www. daff.gov.au>.

59 The tolerance of the ban does not necessarily signify non-compliance with the Panel's findings because the modification of the federal government's measures may have cured the WTO inconsistency with respect to the Tasmanian ban.

60 Japan - Measures Affecting Agricultural Products (Complaint by the United States) (1998), WTO Doc. WT/DS76/R (Panel Report); Japan - Measures Affecting Agricultural Products (Complaint by the United States) (1999), WTO Doc. WT/DS76/AB/R (Appellate Body Report). 
Agreement. Despite the initial opposition to the ruling from the affected agricultural producers, particularly apple producers, the Japanese government withdrew the measure at issue within the agreed period of time for implementation ${ }^{61}$ and introduced a new quarantine measure. However, the dispute was revived less than a year after its resolution. In Japan Apples, the Panel and the Appellate Body again found that Japan's quarantine measures violated the obligations under the SPS Agreement. ${ }^{62}$ Following the adverse ruling by the Panel under art. 21(5) of the $D S U,{ }^{63}$ Japan substantially modified the quarantine measures at issue ${ }^{64}$ and reached a mutually agreed upon solution with the U.S. ${ }^{65}$

What this article focuses on is the impact of the dispute settlement rulings on domestic policies in these cases. Underlying the successful implementation of the DSB recommendations by Japan were the following three noteworthy factors in the political and legal process within Japan. The first factor was the endogenous motive of the Japanese government to conform its measures to Japan's international legal obligations. Although the Japanese government recognized the need to comply with the WTO Agreement, it had not been fully conscious on the specific implications of the SPS Agreement with respect to its quarantine measures until these rulings were issued. The rulings provided the Japanese government the opportunity to update its quarantine measures in accordance with the SPS Agreement. ${ }^{66}$ The second factor is the deferential approach of the dispute settlement system to Japan's measures. That is, the Panel and Appellate Body rulings were limited to only those aspects of the measures at issue that were necessary to be examined in order to resolve the disputes. Moreover, the DSB recommendations did not specify how Japan should bring its measures into conformity with the SPS Agreement. Such a deferential approach allowed the parties to reach flexible solutions to the disputes. ${ }^{67}$ The last, though by no means the least important, factor is the deliberative dialogue that took place between the Japanese government and agricultural producers during and after the dispute settlement proceedings. The dialogue was supported and promoted by the long-standing relationship between them,

61 Japan - Measures Affecting Agricultural Products (2000), WTO Doc. WT/DS76/10 (Communication from Japan).

$62 \quad$ Japan - Apples, Panel, supra note 48; Japan - Apples, Appellate Body, supra note 48.

63 Japan - Measures Affecting the Importation of Apples (Recourse to Article 21.5 of the DSU by the United States) (2005), WTO Doc. WT/DS245/RW (Panel Report). Article 21(5) of the DSU provides that " $[\mathrm{w}]$ here there is disagreement as to the existence or consistency with a covered agreement of measures taken to comply with the recommendations and rulings such dispute shall be [resorted] to the original panel.”

64 Ministry of Agriculture, Forestry and Fisheries Public Notice No. 1327 (25 August 2005).

65 Japan - Measures Affecting the Importation of Apples (2005), WTO Docs. WT/DS245/21, G/L/520/Add.1, G/SPS/GEN/299/Add.1, G/AG/GEN/50/Add.1 (Notification of Mutually Agreed Solution).

66 Satoshi Oyane, “Compliance with International Norms and Domestic Politics: A Constructivist Analysis of Japan - Agricultural Products” in Tsuyoshi Kawase \& Ichiro Araki, eds., Implementation System Under the WTO Dispute Settlement Mechanism (Tokyo: Sanseido, 2005) 137 at 148, 153; see also Study Group on Plant Quarantine, Recommendations Regarding the Future of Japan's Plant Quarantine (May 2004), online: Ministry of Agriculture, Forestry and Fisheries <http://www.maff. go.jp/www/counsil/counsil_cont/seisan/pqkenkyuukai/final_report/report_body.pdf>.

$67 \quad$ For example, in Japan - Measures Affecting Agricultural Products, Japan obtained an agreement from the United States regarding the continued application of a testing requirement for each variety of certain agricultural products, albeit with modifications in the testing methodologies: Japan - Measures Affecting Agricultural Products (2001), WTO Doc. WT/DS76/12 (Communication from Japan and the United States). 
with the Japanese government eventually persuading the producers to accept the rulings. ${ }^{68}$ In a sense, the WTO rulings promoted democratic decision-making within Japan.

\section{Intellectual Property Right Disputes}

Intellectual property rights have been regulated by international legal rules for a long time, though the scope of these rules is relatively limited. The adoption of the Agreement on Trade-Related Aspects of Intellectual Property Rights ${ }^{69}$ in the Uruguay Round has widened and deepened the scope of the international regulation of intellectual property rights, which allegedly reduced the autonomy of WTO member states with respect to intellectual property policies. The objective of this Part is to highlight the remaining autonomy of WTO member states by examining trade-related intellectual property right disputes both in the WTO dispute settlement system and domestic courts and stressing the important role played by domestic courts in domestically implementing the TRIPS Agreement. ${ }^{70}$ It also argues that the TRIPS Agreement has been drafted such that domestic regulatory authorities of the member states may autonomously apply intellectual property laws and policies in accordance with their economic and non-economic needs. ${ }^{71}$ In short, the dispute settlement system leaves discontinuity between member states' intellectual property laws and policies and the obligations under the TRIPS Agreement.

First of all, it is instrumental to mention the general trend of intellectual property disputes in domestic courts as well as in the dispute settlement system. The number of disputes involving the TRIPS Agreement brought under the WTO dispute settlement system remains relatively low. Especially after 2000, only six WTO complaints were brought under the TRIPS Agreement. Moreover, the majority of the TRIPS disputes brought before the dispute settlement system were settled at a relatively early stage of the proceedings, namely, at the consultations stage. The early settlement of the disputes suggests that WTO member states prefer a flexible solution to disputes though consultations as opposed to binding rulings by panels and the Appellate Body in order to allow them to take into account economic and noneconomic priorities. Needless to say, the limited number of TRIPS-related disputes does not necessarily mean that the obligations under the TRIPS Agreement have been fully implemented. Instead, the trend highlights the important role played by the domestic courts in implementing the obligations of the TRIPS Agreement. The amount of domestic intellectual property-related litigation remains high in many developed country WTO

68 Oyane, supra note 66 at 152-54. In Japan - Taxes on Alcoholic Beverages, the lack of an interactive relationship between the government and the industries concerned as well as the conflicting interests among the industries stalled the implementation of the dispute settlement rulings in Japan. In this case, a member of the Diet played a key role in persuading the industries (at 159-62).

6915 April 1994, 1869 U.N.T.S. 299 (entered into force 1 January 1995) [TRIPS Agreement].

70 Cf. Ernst-Ulrich Petersmann, "Multilevel Judicial Governance of International Trade Requires a Common Conception of Rule of Law and Justice” (2007) 10 J. Int'l Econ. L. 529 (Petersmann's multilevel judicial governance of international trade also emphasizes the importance of domestic courts, but it differs from my argument in that it seeks to ensure legal coherence between international law and its domestic implementation).

${ }^{71}$ Cf. Frederick M. Abbott, "WTO Dispute Settlement Practice Relating to the Agreement on TradeRelated Intellectual Property Rights” in Federico Ortino \& Ernst-Ulrich Petersmann, eds., The WTO Dispute Settlement System 1995-2003 (The Hague: Kluwer Law International, 2004) 421. 
member states - even increasing in some. ${ }^{72}$ In resolving intellectual property-related cases, the domestic courts often rely on international legal rules of intellectual property rights, including the provisions of the TRIPS Agreement in interpreting the domestic law.

The active domestic application of the TRIPS Agreement is essential to ensure compliance because intellectual property rights are private in nature and could cause conflicts with the public interest and values of member states. Considering that what the public interest and values are differs in each society, intellectual property rights should be implemented not by international tribunals but by domestic courts that would better understand what the public interest and values are for each society. Such idea is reflected in the structure of the TRIPS Agreement, which assumes that the private rights of intellectual property are protected primarily in the domestic legal orders of WTO member states. It is also noteworthy that the TRIPS Agreement does not articulate in detail how its obligations should be implemented domestically. Therefore, each WTO member state has the discretion to decide how it should domestically implement the obligations of the TRIPS Agreement and whether its courts should directly apply the provisions.

For example, in Canada - Term of Patent Protection, ${ }^{73}$ the case against Canada's Patent $A c t^{74}$ was first brought before the Canadian courts prior to going to the WTO dispute settlement system. In the Federal Court of Canada, Trial Division, Pfizer Inc. claimed that s. 45 of the Patent Act violated art. 33 of the TRIPS Agreement. The Court, having examined the claim, stated that the question before it was whether the TRIPS Agreement was incorporated into domestic law through the World Trade Organization Agreement Implementation Act. ${ }^{75}$ The Court answered in the negative and also denied the right of the plaintiff to directly enforce the TRIPS Agreement through Canadian courts. ${ }^{76}$ Then, the case was brought to the dispute settlement system. In the WTO dispute, Canada-Patent Term, the Panel and the Appellate Body upheld the claim of the complainant, the U.S., and found that s. 45 of the Patent Act was inconsistent with art. 33 of the TRIPS Agreement because it fell short of providing patent protection for a minimum requirement period of 20 years to the applications made prior to a certain threshold application date. ${ }^{77}$

The above ruling suggests a conservative approach adopted by the Canadian Federal Court toward the direct application of the TRIPS Agreement in Canada. The practice in other cases also indicates that Canadian courts are not required to apply international treaties unless the treaties are incorporated into Canada's domestic law through legislative measures. This does not, of course, imply that Canadian courts disregard the TRIPS Agreement. On the contrary, Canadian courts, including the Supreme Court, often refer to international conventions

72

See e.g. Intellectual Property Owners Association (IPOA), IP Suits Filed in U.S. District Courts, 19972006 (Ten-year study), online: IPOA < http://www.ipo.org/AM/Template.cfm?Section=IP_Statistics\& TEMPLATE=/CM/ContentDisplay.cfm\&CONTENTID=14168; "Statistics,” online: Intellectual Property High Court (Japan) <http://www.ip.courts.go.jp/eng/documents/stat_01.html>.

73 Canada - Term of Patent Protection(Complaint by the United States) (2000), WTO Doc. WT/DS170/R (Panel Report) [Canada - Patent Term]; Canada - Term of Patent Protection (Complaint by the United States (2000), WTO Doc. WT/DS170/AB/R (Appellate Body Report).

R.S.C. 1985 , c. P-4.

S.C. 1994 , c. 47.

Pfizer Inc. v. Canada, [1999] 4 F.C. 441 at paras. 34-58 (T.D.).

Canada - Patent Term, supra note 73 at para. 7.1 . 
concerning intellectual property rights, including the TRIPS Agreement, and mention that their rulings are consistent with these conventions. For example, in Merck \& Co. v. Apotex Inc., the Federal Court of Appeal gave consideration to the obligations under the TRIPS Agreement, as well as to the WTO Appellate Body ruling in Canada - Patent Protection of Pharmaceutical Products, ${ }^{78}$ and stated that the product concerned "is to be delivered up

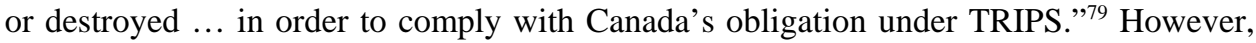
Canadian courts referred to international conventions not because they were required by the conventions to do so but because they chose to do so. ${ }^{80}$ Moreover, given the ambiguity of the language in the Agreement, Canadian courts have leeway as to how to internalize the obligations under the TRIPS Agreement into Canadian law in accordance with the specific social and economic contexts of Canada. ${ }^{81}$ In short, the deference to domestic legal systems under the TRIPS Agreement preserves discontinuity, which gives WTO member states the discretion as to how to adjust their domestic intellectual property law and policy to the rules of the Agreement. This discontinuity is desirable since domestic courts are often better situated than international tribunals, including the dispute settlement system, to fully take into account the public interest and values within a domestic society.

The concern that the international enforcement of intellectual property rights could jeopardize the public interest and values within a society became apparent in Canada Pharmaceutical Patents. In this case, the measures at issue were the "regulatory review exception" and the "stockpiling exception” provided in ss. 55.2(1) and 55.2(2), respectively, of the Patent Act. The former permitted a patent owner's potential competitors to obtain government marketing approval during the term of the patent, and the latter allowed them to manufacture and stockpile patented goods during a certain period before the patent expired. The purpose of the two exceptions was to allow the competitors to be ready to sell their products in competition with the patent owner by the date on which the patent expired. In this case, while the Panel admitted that the "regulatory review exception" was justified by art. 30 of the TRIPS Agreement, it found that the "stockpiling exception" failed to meet the requirements of this provision and was not justified. ${ }^{82}$ Canada withdrew the "stockpiling exception" in order to implement the DSB recommendation. ${ }^{83}$

Robert Howse criticizes the Panel ruling by arguing that the Panel interpreted the TRIPS Agreement largely from the perspective of intellectual property rights holders, and thus, failed to balance their rights with the different social and economic interests of intellectual property users and others. ${ }^{84}$ While the criticism is mostly correct, the real flaw of this ruling in my view is not that the Panel failed to properly balance the competing interests but that

Canada - Patent Protection of Pharmaceutical Products (Complaint by the European Communities) (2000), WTO Doc. WT/DS114/R (Panel Report) [Canada - Pharmaceutical Patents]. 2006 FCA 323, [2007] 3 F.C.R. 588 at para. 124.

Daniel J. Gervais, "The Role of International Treaties in the Interpretation of Canadian Intellectual Property Statutes" in Oonagh E. Fitzgerald, ed., The Globalized Rule of Law: Relationships between International and Domestic Law (Toronto: Irvin Law, 2006) 549 at 553-64.

Ibid. at 567-71.

Canada - Pharmaceutical Patents, supra note 78.

Dispute Settlement Body, Minutes of Meeting, WTO Doc. WT/DSB/M/91 (30 November 2000) at 2223.

Robert Howse, “The Canadian Generic Medicines Panel: A Dangerous Precedent in Dangerous Times” (2000) 3 Journal of World Intellectual Property 493. 
it failed to leave the balancing to the government of Canada. The Panel characterized art. 30 of the TRIPS Agreement as an exception to art. 28 of the TRIPS Agreement, ${ }^{85}$ but this does not rightly reflect the nature of art. 30. A careful reading of arts. 28 and 30 suggests that art. 28 provides for the member states' obligations to confer certain patent rights to patent owners, while art. 30 is not an exception to the member states' obligations but an exception to the patent owners' rights that are to be conferred by the WTO member states through their domestic intellectual property laws. In other words, these provisions authorize the domestic regulatory authorities to define the contours of intellectual property rights provided the stated conditions under the TRIPS Agreement are met. This reading is supported by arts. 7 and 8(1) of the TRIPS Agreement and also in line with the Appellate Body findings on the burden of proof in EC - Hormones. ${ }^{86}$ The corollary of this re-characterization of art. 30 is that it is the member states (either domestic regulatory authorities or courts) who are entitled to balance the rights and obligations of different parties, and the role of panels and the Appellate Body should be limited to the objective assessment of the balancing in accordance with art. 11 of the DSU.

Adding to the significant role of the domestic courts and authorities in the implementation of the TRIPS Agreement is the flexibility in the implementation of DSB recommendations, which also contributes to more discontinuity between the TRIPS Agreement and domestic intellectual property laws and policies. For example, in United States - Section 110(5) of the U.S. Copyright Act, the measure at issue was s. 110(5) of the U.S. Copyright Act, ${ }^{87}$ which places limitations on the copyrights provided for in s. 106 of the Copyright Act in respect of certain performances and displays. The Panel found that one of the limitations failed to meet the requirements of art. 13 of the TRIPS Agreement and could not be justified. ${ }^{88}$ The Panel's finding may not have properly taken into account the nature of art. 13, whose function should be considered as similar to that of art. 30 of the TRIPS Agreement. The Panel's finding could create tension with the ability of the U.S., the respondent, to balance private intellectual property rights and the public interest and values. However, in the end, the flexibility allowed regarding the implementation of DSB recommendations enabled the U.S. and the European Communities, the complainant, to successfully agree on a settlement of the dispute that at least temporarily tolerated the maintenance of the measures that were inconsistent with the TRIPS Agreement. ${ }^{89}$

What can be inferred from the above observations is that discontinuity remains between the TRIPS Agreement and the domestic intellectual laws and policies in the sense that WTO member states may autonomously craft their intellectual property laws and policies in

The Panel examined whether the "stockpiling exception" satisfied the three criteria under art. 30 and concluded that the exception could not be considered a "limited exception" as provided in art. 30 because it constituted a substantial curtailment of the exclusionary rights provided under art. 28(1): Canada - Pharmaceutical Patents, supra note 78 at paras. 7.16, 7.20-7.38. EC - Hormones, supra note 41 at para. 104. 17 U.S.C. $\S 110(5)$ (2006). United States - Section 110(5) of US Copyright Act (Complaint by the European Communities) (2000), WTO Doc. WT/DS160/R at paras. 6.97-6.272 (Panel Report).

United States - Section 110(5) of US Copyright Act (2003), WTO Doc. WT/DS160/23 (Notification of a Mutually Satisfactory Temporary Arrangement); see also United States - Section 110(5) of the US Copyright Act (Recourse to Arbitration under Article 25 of the DSU) (2001), WTO Doc. WT/DS160/ARB25/1 (Award of the Arbitrators). 
accordance with both international conventions and their respective domestic policy preferences.

\section{NoRMATIVE VALUES OF REMAINING DisconTINUITY}

The analysis in the previous Part demonstrates that WTO member states retain the discretion to decide how to implement the adverse rulings of the dispute settlement system into their domestic legal orders. In addition, the panels and the Appellate Body generally review the laws and policies of the member states in a manner such that they do not interfere with the member states' democratic autonomy. However, these analyses do not imply that panels and the Appellate Body afford total deference to WTO member states' laws and policies or that the member states have no international legal obligation to implement the recommendations of dispute settlement rulings into the domestic legal orders. The point is that despite the active use of the dispute settlement system, a certain degree of discontinuity remains between the WTO Agreement and the domestic legal orders, which allows member states to autonomously decide how to pursue their democratically determined policy objectives while at the same time complying with the WTO Agreement.

It may be suggested that discontinuity between international legal rules, including the WTO Agreement and the domestic legal orders, should be removed. In fact, some international law scholars argue that domestic bodies, such as courts and regulators, should play a key role in applying international law domestically, and also that such application should be coherent in both the international and the domestic spheres. ${ }^{90}$ The idea behind this argument is that the rules of modern international law increasingly encroach upon domestic policies in addition to integrating further interstate relations, and therefore such coherence is becoming essential to securing compliance with the rules. ${ }^{91}$

It is true that international legal rules are increasingly necessitating domestic implementation measures in broader policy areas and in more detail. However, it should be emphasized that securing compliance with international law through domestic implementation does not necessarily mean that domestic laws and policies should be coherent with or identical to the rules of international law. As Abram Chayes and Antonia Chayes point out, compliance is not an on-off phenomenon and has a considerable zone within which behavior is accepted as adequately conforming to international law. The acceptable level of compliance is determined and developed on the basis of the perspectives and interests of the states through an ongoing political process. ${ }^{92}$

This article adds to the views of Chayes and Chayes by suggesting that the forms of compliance with international legal rules can also vary depending on the specific sociological contexts within each state. The domestic legal orders are extremely diverse, reflecting the

$90 \quad$ See e.g. Eyal Benvenisti, "Reclaiming Democracy: The Strategic Uses of Foreign and International Law by National Courts” (2008) 102 A.J.I.L. 241 at 249-52; Slaughter, supra note 12 at 12-15; Yishai Blank, “Localism in the New Global Legal Order” (2006) 47 Harv. Int’l L.J. 263.

91 Anne-Marie Slaughter \& William Burke-White, “The Future of International Law is Domestic (or, The European Way of Law)” (2006) 47 Harv. Int'l L.J. 327.

92 Abram Chayes \& Antonia Handler Chayes, The New Sovereignty: Compliance with International Regulatory Agreements (Cambridge: Harvard University Press, 1995) at 17-22. 
diversity of the global society. One international legal rule may acquire distinct and particular meanings in the domestic legal orders of different states, which often have different values, beliefs, and priorities. The fact that an international legal rule is implemented in different ways in different states does not signify that only one or some are in conformity with the rule while the others are not. Instead, many international legal rules leave states ample discretion with respect to how the rules should be implemented in the domestic legal orders, thus acknowledging the diversity of the global society. The search for coherence between international law and domestic law could threaten to efface this diversity. Discontinuity not only is an empirical fact but also has a normative value in that it allows states to adapt international legal rules to their domestic sociological contexts. ${ }^{93}$

The same applies to the WTO dispute settlement system. The rules of the WTO Agreement are expanding to cover not only trade measures but also the non-trade domestic laws, regulations, and policies of the member states. As a result, compliance with the WTO Agreement and the rulings of the dispute settlement system requires domestic implementation and affects both the trade and non-trade laws and policies of the member states, such as environmental and quarantine policies. Requiring a high degree of congruence between the WTO Agreement and domestic laws and policies could jeopardize the policy autonomy of the member states and put the diversity of the global society at risk. Thus, the discontinuity carefully left by the dispute settlement system has a normative value in that it accommodates the diversity of the global society by allowing the member states to adapt the obligations under the WTO Agreement to their sociological contexts.

The normative value of discontinuity is further reinforced when problems ensuing from the democratization of the dispute settlement system are taken into account. In previous works, I pointed out that the democratization of the system raises two critical problems, namely, the representation problem and the coordination problem. ${ }^{94}$ The representation problem means that even if the wider participation of people is allowed in the dispute settlement system, the diverse interests and values of people cannot be fully represented in the system given the existing gaps in resources and capacities among people to represent themselves. The gaps exist not only between people from the developed world and those from the developing world, but also among people from within both the developed and developing world, such as between experts and non-experts and between global NGOs and non-English speaking individuals.

The coordination problem arises from the assumption that the conflicting interests and values of people, once represented in the dispute settlement system, requires the prioritization of some interests and values over others. In the simplest terms, this implies that panels and the Appellate Body would need to coordinate differences among people's views and to decide which of the views of people represented before them should be reflected more, and

Cf. Andreas L. Paulus, "The Emergence of the International Community and the Divide Between International and Domestic Law" in Janne Nijman \& André Nollkaemper, eds., New Perspectives on the Divide Between National and International Law (New York: Oxford University Press, 2007) 216 at 228-34.

94 Fukunaga, "Participation,” supra note 8 at 122-28; see also Yuka Fukunaga, “Civil Society and the Legitimacy of the WTO Dispute Settlement System” (2008) 34 Brook. J. Int’l L. 85. 
which less, in their rulings. In this regard, some argue that the reflection of non-economic interests and values of people would eliminate the alleged "trade bias" of panel and Appellate Body rulings. ${ }^{95}$ However, given the diversity in the interests and values of people and the lack of hierarchy among them, the coordination made by panels and the Appellate Body tends to be regarded as an arbitrary selection of specific interests and values and incapable of delivering full satisfaction to all people, as well as the WTO member states.

Given these problems ensuing from the democratization of the dispute settlement system, discontinuity has an advantage in that it preserves and promotes national democracy within the territory of the WTO member states instead of requiring democratization of the dispute settlement system.

Last, it is worth mentioning the implications of discontinuity for the ongoing debate on the fragmentation of international law. In the absence of central law-making and lawapplying authorities, the rules of international law have been developed in a fragmented manner, which increases the possibility of conflicts among international legal rules. Interestingly, the argument that discontinuity should be removed is often accompanied by a separate argument that the fragmentation of international law needs to be resolved because the fragmentation could directly distort the domestic laws and policies through the "continuous" internalization process of international law. ${ }^{96}$ According to this view, a "transnational" or "global" legal order, ${ }^{97}$ in which international law and domestic law are inextricably interwoven, is emerging and coherence and unity is required therewith. In the more specific context of the WTO dispute settlement system, some scholars argue that panels and the Appellate Body should not only apply the rules of the WTO Agreement but also nonWTO international legal rules ${ }^{98}$ to bring coherence and unity between them and thereby avoid distorting domestic laws and policies in favour of trade interests.

However, as a recent study by the International Law Commission admits, the current international legal rules concerning the interpretation of treaties fail to resolve the fragmentation. ${ }^{99}$ In addition, most international legal rules lack universality or hierarchy among them. ${ }^{100}$ Given this situation, it is doubtful that panels and the Appellate Body are

95 Steve Charnovitz, “Opening the WTO to Nongovernmental Interests” (2000) 24 Fordham Int’l. L.J. 173 at 209-10; Andrew T. Guzman, “Global Governance and the WTO” (2004) 45 Harv. Int'l L.J. 303 at 313-16, 331-33; Andrew T.F. Lang, "Reconstructing Embedded Liberalism: John Gerard Ruggie and Constructivist Approaches to the Study of the International Trade Regime” (2006) 9 J. Int'l Econ. L. 81. Cf. Yuval Shany, The Competing Jurisdictions of International Courts and Tribunals (Oxford: Oxford University Press, 2003); Yuval Shany, Regulating Jurisdictional Relations Between National and International Courts (Oxford: Oxford University Press, 2007). See supra notes 12-13 and accompanying text.

98 See e.g. Joost Pauwelyn, "Bridging Fragmentation and Unity: International Law as a Universe of InterConnected Islands” (2004) 25 Mich. J. Int’l L. 903; see also supra notes 5-6 and accompanying text.

99 Study Group of the International Law Commission, Fragmentation of International Law: Difficulties Arising from the Diversification and Expansion of International Law, 58th Sess., UN Doc. A/CN.4/L.682 (2006).

100 Although some international legal rules claim universality for the entire international community, a judgment on whether a rule acquires universality can be relative to each society. Furthermore, even if a rule with universality exists, it does not necessarily mean that the rule should be applied coherently in every context; cf. Martti Koskenniemi, "International Law in Europe: Between Tradition and Renewal” (2005) 16 E.J.I.L. 113; Onuma Yasuaki, Human Rights, States, and Civilizations: From a 
capable of resolving the conflicts between the WTO rules and non-WTO international legal rules in an effective and legitimate manner. ${ }^{101}$ Moreover, there is a question as to whether the application of non-WTO international legal rules by panels and the Appellate Body brings coherence and unity in international law. ${ }^{102}$ Naturally, one rule may acquire different meanings depending on the context. The application of a non-WTO international legal rule by panels and the Appellate Body does not necessarily inform non-WTO tribunals of the meanings of the rule since the rule may acquire particular contextual meanings that are different from those ascribed to it when applied in the WTO. In this regard, discontinuity shows strengths since it prevents the fragmentation of international law from directly distorting domestic laws and policies. Instead, it enables each state to resolve the fragmentation in the domestic legal order, in accordance with its own interests and values. In a sense, discontinuity can help domestic laws to supplement the lack of conflicts of laws rules within international law.

\section{ConCLUSION}

The WTO dispute settlement system has been severely criticized for its democratic deficit. International law scholars and practitioners are actively making proposals for democratizing the system. The factual premise underlying the democratic deficit critique is that the national democratic autonomy of WTO member states is being eroded by the active enforcement of the WTO Agreement through the dispute settlement system and, therefore, that the eroded autonomy should be supplemented by the democratization of the system itself. This article critically assessed this premise and revealed that discontinuity between the rules of the WTO Agreement and the domestic legal orders remains, and that the democratic autonomy of the member states is kept intact. This article also pointed out the normative value of discontinuity that accommodates the diversity of the global society. The empirical analysis and normative implications of discontinuity raise a serious doubt as to whether the WTO dispute settlement system needs to be democratized.

There is no doubt that the relationship between the international legal order and the domestic legal orders is becoming increasingly dynamic as the scope of international law continues to expand and its application is strengthened. The international law process should no longer be monopolized by states and non-state actors, such as individuals and NGOs, should be given a say as legitimate stakeholders in the process. However, these new developments do not allow us to jump to the conclusion that the international law process should be democratized. The stronger the pull toward coherence and unity, the stronger our desire to preserve the diversity of the global society. The democratization of the international law process may contradict this desire.

Universalistic Perspective to an Intercivilizational Perspective of Human Rights (Tokyo: Chikuma Shobo, 1998).

101 The application of conflicting non-WTO international legal rules can also contradict the rules of the DSU; cf. Joel P. Trachtman, “The Domain of WTO Dispute Resolution” (1999) 40 Harv. Int'l L.J. 333 at 342-43; Yuji Iwasawa, "The Interaction between WTO Law and Non-WTO Law” (2003) 1254 Jurist 20 at $22-23$.

102 Cf. Martti Koskenniemi, From Apology to Utopia: The Structure of International Legal Argument (Cambridge: Cambridge University Press, 2005) at 597-98. 